\section{Synthesis of Digestive Enzyme in the Fleshfly Sarcophaga bullata stimulated by Food}

INGESTION of proteinaceous but not of non-proteinaceous foods is followed by an increased level of proteolytic enzymes in the midgut of Aedes aegypti ${ }^{1,2}$ and Leucophaea maderae ${ }^{3,4}$ as well as in other insect species. 'Two hypotheses have been advanced to explain the mechanism by which certain foods cause enzyme synthesis and/or relcase into the gut lumen: $(a)$ certain foods might act as secretagogues, that is, chemicals which elicit enzyme synthesis in the gut cells with which they come in contact, or $(b)$ food intake might trigger the release of hormones which in turn stimulate enzyme synthesis. We tested these two proposed mechanisms with the fleshfly Sarcophaga.

In an exporimental group of females, the neurosecretory cells of the pars intercerebralis were removed with fine tungsten needles 4-6 $\mathrm{h}$ after emergence. Theso operated females as well as sham and non-operated control animals were fed a sucrose solution for the following 2 days and then starved for a further 2 days. All the animals were then individually offered a chicken liver homogenate of known protein concentration in calibrated capillary tubes. The amounts of food ingested could thus be accurately determined. Within a period of $2 \mathrm{~h}$ the thirty-six controls, which had not been subjected to operation, ingested $32 \cdot 4+2 \cdot 0$ ul. (about $810 \mathrm{ug}$ of protein), whereas the twenty-four females, which we operated on, took $15 \cdot 8 \pm 2 \cdot 6 \mu \mathrm{l}$. (about $370 \mu \mathrm{g}$ of protein). Somo operated and sham operated animals did not eat at all within the $2 \mathrm{~h}$ period. It thus became clear that the animals with brain surgery ate only about half of the amount of liver homogenate compared with normal animals kept in otherwise identical conditions.

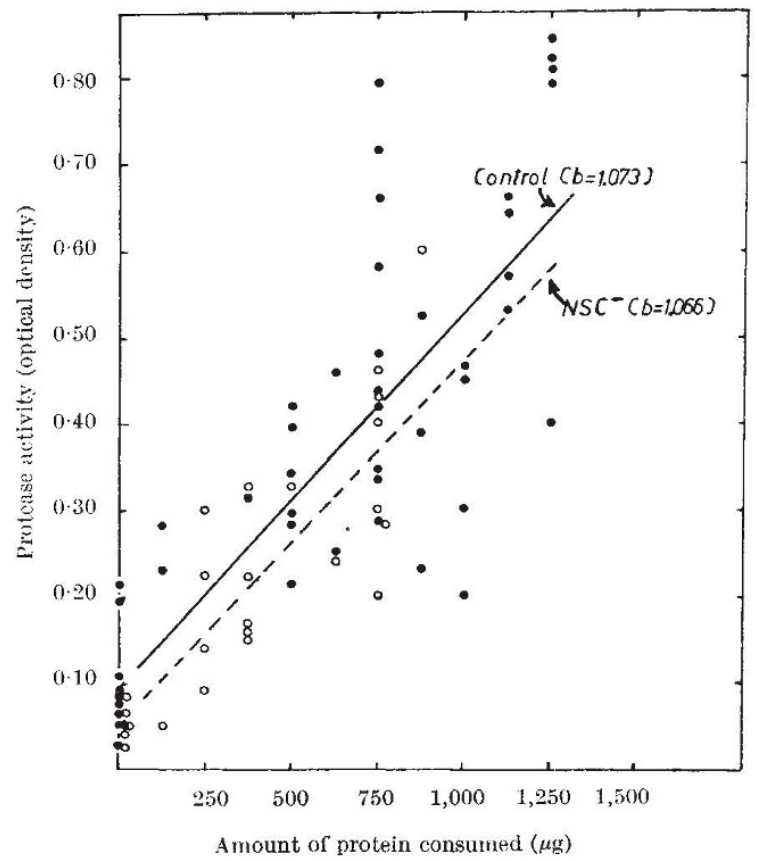

Fig. 1. Correlation of amount of protein ingested during one meal and protease activity in the midgut in normal and sham operated female controls ( ) and in females whose neurosecretory cells of the par

Five to $8 \mathrm{~h}$ after the meal the animals were opened and the midgut, without the Malpighian tubules, was homogenized in $0.5 \mathrm{ml}$. of saline. After centrifugation of the homogenate at low speed, a casein-urea substrate was incubated with $0.1 \mathrm{ml}$. of the supernatant solution at $37^{\circ} \mathrm{C}$ and $p \mathrm{H} 7 \cdot 5$. A blank for each assay consisted of boiled enzyme solution, substrate and buffer. At the end of the $3 \mathrm{~h}$ incubation period, the non-digested substrate was precipitated with 10 per cent trichloracetic acid (TCA). In this assay the amount of non-precipitablo aromatic amino-acids, assayed by the Lowry method ${ }^{5}$. varies linearly with the amount of substrate digested ${ }^{3,4,6}$.

The enzyme level in the midgut of Sarcophaga is proportional to the amount of liver juice ingested (Fig. 1) in both control and operated animals. No significant difference exists between the two groups of animals. In both non-operated controls and operated animals digestive enzymes are produced in response to and in proportion to the amount of proteinaceous food ingested. We therefore postulate that in Sarcophaga digestive enzyme synthesis is stimulated by secretagogues contained in the food. Feeding on a sucrose solution did not cause an elevated enzyme level in the midgut.

Removal of the neurosecretory cells of the pars intercerebralis from the blowfly Calliphora erythrocephala was reported to be followed by reduced midgut enzyrne synthesis ${ }^{7,8}$. Food intake, however, was not measured in this latter species, and, just as in Sarcophaga and Leucophaea $^{3,4}$, operated animals may have ingosted less than the controls. Reduced enzyme levels may thus reflect reduced food intake in this species as well.

In several series of both control and operated animals, it has been found that even after large amounts of food had been ingested enzyme activity was very low. Further tests revealed that beef liver from certain sources but not from others contained a powerful enzyme inhibitor but chicken liver never contained an inhibitor. The nature of the inhibitor in some beef livers is not known. Malpighian tubules contained a weak enzyme inhibitor; they were therefore carefully removed from the midgut before homogenization and assay.

In Sarcophaga we have no evidence for neurosecretory involvement in digestive enzyme synthesis. Furthermore, there is no unequivocal information for any insect species that hormones directly control digestive enzyme synthesis; there may be, however, indirect involvement of hormones in certain cases ${ }^{4}$.

This work was supported by grants from the US National Science Foundation (to F. E.) and by a US Public Health Service research training grant (to J. L. W.) administered by the Brain Research Institute, University of California, Los Angoles.

\section{Franz Frgatmany}

Department of Zoology, University of California, Los Angeles,

California 90024.

\section{JERREL L. WILKENS}

Department of Biology,

University of Calgary,

Calgary,

Alberta,

Canada.

Received Webruary 12; reviscd March 19, 1969.

${ }^{1}$ Fisk, F. W., Ann. Entomol. Soc. Amer., 43, 555 (1950).

${ }^{2}$ Shambaugh, G. F., Ohio J. Sci., 54, 151 (1954).

${ }^{3}$ Fngelmann, F., Naturwissenschaften, 53,113 (1966).

- Engelmann, F. J., Insect Physiol., 15, 271 (1969).

${ }^{5}$ Lowry, O. H., Rosenbrough, N. J., Farr, A. L., and Randall, R. J., .J. Biol. Chem., 193, 267 (1951).

'Duspiva, F., Protoplasma, 32, 209 (1939).

'Thomsen, E., and Moller, I., Nature, 183, 1401 (1959).

s Thomsen, E., and Møller, I., J. Exp. Biol.. 40, 301 (1963). 